\title{
MENINGKATKAN KEMAMPUAN WRITING DENGAN PENERAPAN MODEL PEMBELAJARAN KOOPERATIF THINK-PAIR-SHARE BERBANTUAN METODE PENUGASAN DAN RESITASI DENGAN KLIPING BERITA di SMP NEGERI 4 DENPASAR
}

\author{
Ni Made Aryawati \\ Sekolah Menengah Pertama Negeri 4 Denpasar \\ Email: madearyawati14@gmail.com
}

\begin{abstract}
ABSTRAK
Pelaksanaan penelitian tindakan kelas ini adalah untuk mengetahui apakah model Pembelajaran Kooperatif Think-Pair-Share berbantuan metode penugasan dan resitasi dengan kliping berita berhasil dalam mengupayakan untuk meningkatkan prestasi belajar menulis/writing. Penelitian ini mengambil subjek pada kelas VII-6 SMP Negeri 4 Denpasar yang belajar pada semester II tahun pelajaran 2017/2018. Dengan giat dan gigih peneliti mengupayakan agar proses pembelajaran dapat terlaksana sesuai harapan yang ada, menggunakan strategi yang tepat dan teknik-teknik pembelajaran yang memadai. Data hasil penelitian ini dikumpulkan dengan tes prestasi belajar sedangkan analisisnya menggunakan analisis deskriptif. Setelah semua data dilakukan analisis, diperoleh peningkatan hasil belajar dari awalnya mencapai 67,11 dengan ketuntasan belajar 36,11\%, meningkat pada siklus I menjadi 71,97 dengan ketuntasan belajar 72,22\%. Hasil siklus ke II mencapai rata-rata 80,58 dengan persentase ketuntasan belajar sudah mencapai 100\% dan ternyata sudah melampaui kriteria yang diusulkan sesuai indikator keberhasilan penelitian. Atas dasar perolehan data tersebut peneliti berkesimpulan bahwa model pembelajaran kooperatif Think-Pair-Share melalui metode penugasan dan resitasi dengan kliping berita mampu meningkatkan prestasi belajar menulis/writing peserta didik di sekolah ini.
\end{abstract}

Kata kunci: think-pair-share, metode penugasan dan resitasi, prestasi belajar

\section{ABSTRACT}

This class action research aimed at finding out whether cooperative learning models Think-Pair-Share assisted with the assignment and recitation methods with news clippings is successful to improve the students achievement in writing skills. This research took a subject in class VII-6 SMP N 4 Denpasar at semester 2 academic year 2017/2018. The researcher has strived diligently so that the learning process can be carried out accordance with expectations, using the right strategies and adequate learning techniques. The result of the study were collected by learning achievement tests while the analysis used descriptive analysis. After all data is analyzed, it obtained an increase in learning outcomes from the beginning 67,11 with mastery learning 36,11\%, increase in the first cycle to be 71,97 with mastery learning $72,22 \%$. The result of the second cycle is 80,58 with the percentage of mastery learning has reached $100 \%$ and it has exceeded the criteria set for the research indicators. Based on the data obtained, the researcher concluded that cooperative leaning Think- Pair-Share through assignment and recitation methods with news clipping can improve the students writing skills in this school.

Keywords: think-pair-share, assignment and recitation methods, students achievement. 
PENDAHULUAN

Kebenaran di lapangan jauh berbeda antara harapan yang ada. Kekurangan-kekurangan yang ada selama pelaksanaan pembelajaran yang dilakukan guru selama ini yaitu: 1) kurangnya kemampuan guru memotivasi peserta didik untuk giat belajar, 2) guru masih mengandalkan metode ceramah, 3) lingkungan belajar peserta didik kurang mendukung, 4) ketidakmampuan guru mengajar dengan metode, strategi, pendekatan-pendekatan serta model-model pembelajaran yang baru, 5) dipihak siswa terlihat bahwa mereka masih lebih senang santai daripada giat belajar. 
Kelemahan-kelemahan tersebut apabila dibandingkan dengan tuntutan agar peserta didik giat bekerja, giat melakukan, giat berdemonstrasi, ternyata berbanding terbalik karena apa yang dituntut adalah kemampuan guru melaksanakan pembelajaran yang baik agar: 1) Siswa memiliki kebutuhan dan minat untuk belajar, (2) diberi kesempatan berpartisipasi secara aktif dalam berbagai macam aktivitas, (3) Guru memfokuskan pembelajarannya kepada bentuk, keterampilan, dan strategi untuk mendukung proses, (4) guru harus menyadari akan peran dan fungsi mata pelajaran yang diampunya, (5) guru harus giat memberi umpan balik yang tepat menyangkut kemajuan mereka, Guru yang professional hendaknya dapat memilih dan menerapkan metode yang efektif agar materi yang dipelajari oleh siswa dapat dipahami dengan baik serta dapat meningkatkan prestasi belajar. Jika perlu variatif metode pembelajaran dapat diterapkan secara bersamaan untuk mendapatkan hasil yang maksimal dari pembelajaran (Uno, 2008). Untuk itu guru harus mempunyai kreatifitas dan inovasi baru dalam meningkatkan kemampuan dan teknik mengajarnya. Kemampuan teknik mengajar akan sangat berguna untuk membantu siswa mencapai tingkat ketuntasan belajar yang diharapkan.
Pendidikan di sekolah memegang peranan penting dalam rangka mewujudkan tercapainya pendidikan nasional secara optimal seperti yang diharapkan (Suryabrata, 2002). Proses belajar mengajar merupakan inti dari proses pendidikan. Dalam proses belajar mengajar tersebut guru menjadi pemeran utama dalam menciptakan situasi interaktif yang edukatif, yakni interaksi antara guru dengan siswa, siswa dengan siswa dan dengan sumber pembelajaran dalam menunjang tercapainya tujuan belajar.

Demikian harapan-harapan yang ada dipihak guru. Fakta yang ada di lapangan adalah guru belum mampu memenuhi semua harapan atau tuntutan tertentu dalam pendidikan. Datanya terlihat dari prestasi belajar Bahasa Inggris, yang merupakan hasil tes awal yang diberikan kepada siswa kelas VII-6 semester II tahun pelajaran 2017/2018 SMP Negeri 4 Denpasar ternyata masih belum mencapai standar minimal seperti yang ditetapkan. Nilai rata-rata hanya mencapai 67,11 dengan ketuntasan belajar $36,11 \%$.

Adanya kesenjangan antara harapan dengan kenyataan di lapangan diambillah langkah untuk memperbaiki prestasi belajar siswa yaitu dengan tindakan perbaikan yang selanjutnya disusun dalam bentuk penelitian tindakan kelas. Pada langkah awal guru mencari masalah-masalah yang mengganggu dan menghambat penguasaan siswa terhadap mata pelajaran tersebut sehingga dapat meningkatkan penguasaan materi dan hasil belajar siswa. Setelah permasalahan didapat maka dilakukan tindakan dengan penggunaan metode dan model pembelajaran yang lebih konstruktivis untuk meningkatkan prestasi belajar mereka. 
Dengan melihat kesenjangan antara harapan dan kenyataan yang terjadi, mengharuskan peneliti sebagai guru harus mencari solusi untuk memperbaiki masalah ini. Solusi tersebut adalah mengupayakan strategi pembelajaran dengan pemakaian model pembelajaran yang efektif untuk meningkatkan prestasi belajarsiswa di kelas. Pembelajaran yang berhasil pada umumnya ditunjukan dengan dikuasainya materi pembelajaran oleh siswa, dan tingkat pemahaman siswa terhadap materi pembelajaran yang biasanya dinyatakan dengan nilai. Untuk itu, peneliti memilih model Kooperatif untuk mengatasi masih rendahnya prestasi belajar menulis siswa, karena model Kooperatif mempunyai langkah-langkah: Thinking (berpikir), guru mengajukan pertanyaan atau isu yang berhubungan dengan pelajaran. Selanjutnya siswa diminta untuk memikirkan jawaban dari pertanyaan atau isu tersebut secara mandiri untuk beberapa saat. Pairing (berpasangan), guru meminta siswa berpasangan dengan siswa lain untuk mendiskusikan apa yang telah dipikirkan pada tahap I, intraksi pada tahap ini diharapkan siswa dapat berbagi jawaban atau ide. Biasanya guru memberi waktu 45 menit untuk berpasangan. Sharing (berbagi), guru meminta kepada pasangan untuk berbagi dengan seluruh kelas apa yang telah dibicarakan. Ini dapat dilakukan dengan cara bergiliran pasangan demi pasangan sampai sekitar seperempat pasangan telah mendapat kesempatan untuk melaporkan. Jadi, pembelajaran kooperatif merupakan jenis pembelajaran yang dirancang untuk mempengaruhi pola intraksi siswa. Agar rancangan pola perilaku lebih spesifik, guru memanfaatkan berita sebagai media pembelajaran. Kliping berita di samping bisa dimanfaatkan sebagai hiburan bagi siswa juga dapat dimanfaatkan sebagai alat untuk membelajarkan siswa. penugasan untuk menulis kliping berita dalam bahasa Inggris secara intensif akan dapat melatih siswa untuk belajar membiasakan menulis dalam bahasa Inggris. Pemilihan media tesebut sesuai dengan tuntutan belajar bemakna dan menyenangkan. Apabila media yang digunakan sudah menyenangkan sudah dapat dipastikan belajar akan lebih efektif dan efisien.

Rumusan masalah pada dasarnya merupakan suatu pertanyaan yang ada dan keadaan yang diinginkan. Sehubungan dengan itu, maka masalah yang dapat peneliti rumuskan adalah: Apakah penerapan model pembelajaran kooperatif Think -Pair-Share berbantuan metode penugasan dan resitasi dengan kliping berita dapat meningkatkan prestasi belajar writing siswa kelas VII-6 tahun pelajaran 2017/2018 SMP Negeri 4 Denpasar?

Penelitian tindakan kelas ini dilakukan untuk mengatasi berbagai persoalan nyata guna memperbaiki atau meningkatkan kualitas peoses pembelajaran di kelas (Sanjaya, 2006). Apa yang menjadi tujuan dalam penelitian ini disampaikan sebagai berikut ; 1) Tujuan umum: Untuk mengetahui peningkatan kualitas pembelajaran setelah diterapkan model kooperatif think-pairshare dan dapat memberi kontribusi terhadap dunia pendidikan, khususnya dalam peningkatan kualitas pembelajaran. 2) Tujuan khusus: Untuk mengetahui peningkatan prestasi belajar writing setelah penerapan model pembelajaran kooperatif think-pair-share berbantuan metode penugasan dan resitasi kliping berita dalam belajar Bahasa Inggris.

Setiap kegiatan penelitian tentu 
diupayakan untuk dapat bermanfaat. Dengan demikian maka penelitian ini diharapkan dapat dirasakan bagi berbagai kalangan seperti: 1) Bagi siswa, penelitian dengan menerapkan model pembelajaran kooperatif melalui penugasan dan resitasi dapat meningkatkan prestasi belajar menulis dalam mata pelajaran Bahasa Inggris. 2) Bagi guru, hasil penelitian ini dapat digunakan sebagai alternative solusi penanggulangan permasalahan pembelajaran, dan secara serta merta mengindikasikan profesionalisme guru dalam pengelolaan kelas dan kualitas pembelajaran. 3) Bagi sekolah, hasil penelitian ini dapat dipergunakan sebagai referensi dalam mengatasi permasalahan rendahnya output dan outcome pendidikan di sekolah ini.

Siswa yang belajar dalam situasi pembelajaran kooperatif didorong dan dikehedaki untuk bekerjasama untuk suatu tugas besama, dan mereka harus mengkordinasikan usahanya untuk menyelesaikan tugasnya. Dalam penerapan pembelajaran kooperatif dua individu atau lebih saling bergantung satu sama lain untuk mencapai suatu penghargaan bersama. Mereka akan membagi penghargaan tersebut seandainya mereka berhasil sebagai kelompok Ibrahim dalam (Astrini, 2005).

Model pembelajaran kooperatif dikembangkan untuk mencapai setidaktidaknya tiga tujuan pembelajaran yaitu: 1) Hasil belajar akademik: Model struktur penghargaan kooperatif dapat meningkatkan penilaian siswa pada belajar akademik dan perubahan norma yang berhubungan dengan hasil belajar. Disamping itu, pembelajaran kooperatif juga dapat memberikan keuntungan baik pada siswa kelompok bawah maupun kelompok atas yang bekerjasama menyelesaikan tugas-tugas akademik. 2) Penerimaan terhadap individu: Pembelajaran kooperatif memberikan peluang kepada siswa yang berbeda latar belakang dan kondisi untuk bekerja saling begantung satu sama lain atas tugas-tugas bersama, dan melalui penggunaan strukur penghargaan kooperatif, belajar untuk menghargai satu sama lain. 3) Pengembangan keterampilan: Pembelajaran kooperatif membantu siswa untuk menumbuhkan keterampilan kerjasama dan kolaborasi. Keterampilan ini amat penting untuk dimiliki di dalam masyarakat, dimana banyak kerja orang dewasa sebagian besar dilakukan dalam organiasi yang saling bergantung satu sama lain dan masyarakat secara budaya semakin beragam (Mahaputri, 2003).

Model kooperatif tipe TPS merupakan salah satu tipe dalam pembelajaran kooperatif yang dikembangkan oleh Frank Lyman, (1985) dalam Pujawan (2001). Teori pembelajaran kooperatif menekankan bahwa siswa belajar paling baik ketika mereka dapat saling mendorong dan membimbing satu sama lain, memiliki tanggung jawab perseorangan, masingmasing siswa memberikan partisifasi secara maksimal dan terdapat kesempatan aktif intraaktif. Tipe TPS merupakan jenis pembelajaran yang dirancang untuk mempengaruhi pola intraksi siswa. Struktur yang dikembangkan dimaksudkan sebagai alternatif terhadap struktur kelas tradisional. Struktur ini menghendaki siswa bekerja saling membantu dalam kelompok kecil (2-6 anggota) dan lebih bercirikan penghargaan kooperatif dari pada individu. Tipe TPS memiliki prosudur yang ditetapkan secara eksplisist untuk memberi siswa memilih menggunakan TPS sebagai ganti tanya 
jawab seluruh kelas langkah-langkah adalah sebagai berikut: 1) Guru menyampaikan inti materi dan kompetensi yang ingin dicapai. 2) Siswa diminta untuk berpikir tentang materi/permasalahan yang disampaikan guru. 3) Siswa diminta berpasangan dengan teman sebelahnya (kelompok 2 orang) dan mengutarakan hasil pemikiran masing-masing. 4) Guru memimpin pleno kecil diskusi, tiap kelompok mengemukakan hasil diskusinya. 5) Berawal dari kegiatan tersebut mengarahkan pembicaraan pada pakok permasalahan dan menambah materi yang belum diungkapkan para siswa. 6) Guru memberi kesimpulan.

Salah satu tipe pendekatan struktural adalah tipe TPS merupakan salah satu tipe dalam pembelajaran kooperatif yang dikembangkan oleh Frank Lyman, (1985) untuk melibatkan lebih banyak siswa dalam menelaah materi yang mencangkup dalam suatu pelajaran dan mengecek pemahaman mereka terhadap isi pelajaran tersebut(Winkel, 2004). Pendekatan ini dirancang untuk mempengaruhi pola intraksi siswa dan sebagai alternatif terhadap struktur kelas pembelajaran yang bepusat pada guru (tradisional). Sebagai gantinya mengajukan pertanyaan kepada seluruh kelas, guru menggunakan sruktural tiga langkah berikut ini(Jatmiko, 2008).

Tahap I. Thinking (berpikir). Guru mengajukan pertanyaan atau isu yang berhubungan dengan pelajaran. Selanjutnya siswa diminta untuk memikirkan jawaban dari pertanyaan atau isu tersebut secara mandiri untuk beberapa saat

Tahap II. Pairing (berpasangan). Guru meminta siswa berpasangan dengan siswa lain untuk mendiskusikan apa yang telah dipikirkan pada tahap I. Intraksi pada tahap ini diharapkan siswa dapat berbagi jawaban atau ide. Biasanya guru memberi waktu 4-5 menit untuk berpasangan.

Tahap III. Sharing (berbagi). Guru meminta kepada pasangan untuk berbagi dengan seluruh kelas apa yang telah dibicarakan. Ini dapat dilakukan dengan cara bergiliran pasangan demi pasangan sampai sekitar seperempat pasangan telah mendapat kesempatan untuk melaporkan(Jatmiko, 2008).

Metode tugas dan resitasi adalah suatu cara penyajian pelajaran dengan cara guru memberi tugas tertentu kepada siswa dalam waktu yang telah ditentukan dan siswa mempertanggungjawabkan tugas yang dibebankan kepadanya (Moh. Uzer Usman, 1993 : 125). Syaiful Bahri Djamarah dan Aswan Zain (2002) menyatakan bahwa metode tugas dan resitasi adalah metode penyajian bahan dimana guru memberikan tugas tertentu agar siswa melakukan kegiatan belajar. Tugas dan rersitasi merangsang siswa untuk aktif belajar baik secara individu maupun kelompok (dikutif dari Siti Masruroh: 2006: 12).

Metode tugas dan resitasi tidak sama dengan pekerjaan rumah, tetapi lebih luas dari itu(Depdiknas, 2008). Tugas dan resitasi merangsang anak untuk aktif belajar baik secara individu atau kelompok. Tugas dan resitasi bisa dilaksanakan di rumah, di sekolah, di perpustakaan dan tempat lainnya. Adapun langkah-langkah yang harus diikuti dalam 
penggunaan tugas dan resitasi adalah sebagai berikut.

a) Fase pemberian tugas

Tugas yang diberikan kepada siswa hendaknya mempertimbangkan hal-hal sebagai berikut.

1) Tujuan yang akan dicapai

Tujuan yang akan dicapai dalam pemberian tugas dan resitasi pada bidang studi Bahasa Inggris yaitu untuk memacu siswa agar selalu siap belajar tetapi jangan sampai terjadi kebiasaan siswa baru akan melakukan belajar jika metode ini akan diterapkan dalam pembelajaran pada pertemuan berikutnya.

2) Jenis tugas yang jelas dan tepat Jenis tugas yang diberikan khususnya pada bidang studi bahasa Inggris harus jelas dan tepat, sehingga siswa mampu menyelesaikan tugas-tugas tersebut setelah guru memberikan materi pelajaran.

3) Tugas yang diberikan harus sesuai dengan kemampuan siswa.

4) Ada petunjuk atau sumber yang dapat membantu pekerjaan siswa seperti buku paket dari guru atau lembar kerja siswa (LKS).

5) Diharapkan siswa menyediakan waktu yang cukup untuk mengerjakan tugas menulis/menyalin paragraf Bahasa Inggris.

b) Fase pelaksanaan tugas.

Langkah ini meliputi hal-hal sebagai berikut.

1) Diberi bimbingan berupa penjelasan materi pada pokok bahasan tertentu dalam bidang studi bahasa Inggris atau diberi pengawasan dalam pelaksanaan tugas oleh guru.

2) Sebelum melaksanakan tugas seharusnya siswa diberikan dorongan sehingga siswa mau bekerja.

3) Diusahakan dikerjakan oleh siswa sendiri tidak menyuruh orang lain

4) Dianjurkan agar siswa mencatat hasil-hasil yang telah dikerjakan dengan baik dan sistematik.

c) Fase mempertanggungjawabkan tugas Hal-hal yang harus dikerjakan dalam fase ini adalah:

1) Laporan siswa baik lisan maupun tulisan dari apa yang telah dikerjakan pada lembar kerja yang diberikan oleh guru.

2) Ada tanya jawab atau diskusi kelas tentang soal-soal yang diberikan sehingga guru mengetahui apakah siswa mengerjakan tugas tersebut sendiri atau menyuruh orang lain.

3) Penilaian hasil pekerjaan siswa dengan tes maupun non tes atau cara lainnya.

Arini dalam artikel di blog-nya menyampaikan bahwa dalam proses pembelajaran menulis, ada beberapa kategori kegiatan menulis yang bisa dijadikan tugas ketika melakukan aktivitas di dalam ruang kelas yang dikemukakan oleh Brown, Douglas, Teaching by Principles, (2001) sebagai berikut: a) Menyalin (imitative writing), b) Intensif atau terkontrol (Intensive/Controlled Writing), c) Menulis mandiri (SelfWriting), d) Tulisan ilmiah (Display Writing) e) Tulisan otentik (Real Writing). Untuk pembelajaran di sekolah menengah, agar tidak terlalu memberatkan, maka jenis menulis yang diajarkan adalah menyalin atau menulis ulang sesuatu yang dalam penelitian ini dengan memberikan tugas menulis kliping 
berita.

Pada dasarnya prestasi belajar yang diharapkan di sekolah merupakan hasil yang dicapai peserta belajar setelah mengikuti, mengerjakan tugas, dan kegiatan pembelajaran, guru selaku peneliti menyampaikan beberapa gambaran pendapat dari para ahli tentang hal tersebut.

Prestasi belajar atau hasil belajar adalah realisasi atau pemekaran dari kecakapan potensial atau kapasitas yang dimiliki seseorang.Penguasaan prestasinya bila dilihat dari perilakunya, baik dalam bentuk perilaku penguasaan pengetahuan keterampilan berfikir maupun kemampuan motorik. Ada dua pendekatan didalam pelaksanaan pengajaran disekolah yaitu pendekatan yang mengutamakan hasil belajar dan menekankan proses belajar. Sesungguhnya diantara kedua pendekatan tersebut tidak terdapat perbedaan, sebab suatu hasil belajar yang baik akan diperoleh melalui proses yang baik pula (Sukmadinata, 2005).

Marsun dan Martaniah (dikutif dari Tjundjing, 2001) berpendapat bahwa prestasi belajar merupakan hasil kegiatan belajar, yaitu sejauh mana peserta didik menguasai bahan pelajaran yang diajarkan, yang diikuti oleh munculnya perasaan puas bahwa ia telah melakukan sesuatu dengan baik. Hal ini berarti prestasi belajar hanya bisa diketahui jika telah dilakukan penilaian terhadap hasil belajar siswa.

Agus Suprijono (2010)

berpendapat bahwa prinsip belajar itu ada tiga: Pertama, prinsip belajar adalah perubahan perilaku. Kedua, belajar merupakan proses yang terjadi karena didorong kebutuhan dan tujuan yang ingin dicapai, dan prinsip yang ketiga adalah belajar merupakan bentuk pengalaman.

Menurut Ngalim Purwanto (2010), faktor-faktor yang mempengaruhi prestasi belajar adalah : a) Faktor dari dalam diri individu: Terdiri dari faktor fisiologis.Faktor fisiologis adalah kondisi jasmani dan kondisi panca indera.Sedangkan faktor psikologis yaitu bakat, minat, kecerdasan, motivasi berprestasi dan kemampuan kognitif. b) Faktor dari luar individu: Terdiri dari faktor lingkungan dan faktor instrumental.Faktor lingkungan yaitu lingkungan sosial dan lingkungan alam.Sedangkan faktor instrumental yaitu kurikulum, bahan, guru, sarana, administrasi, dan manajemen. 
Kata kunci dari belajar adalah perubahan perilaku.Moh. Surya (2004) mengemukakan ciri-ciri dari perubahan perilaku, yaitu: 1) Perubahan yang disadari dan disengaja (intensional); Perubahan perilaku yang terjadi merupakan usaha sadar dan disengaja dari individu yang bersangkutan. 2) Perubahan yang berkesinambungan(kontinyu); Bertambahn ya pengetahuan atau keterampilan yang dimiliki pada dasarnya merupakan kelanjutan dari pengetahuan dan keterampilan yang telah diperoleh sebelumnya. 3) Perubahan yang fungsional; Setiap perubahan perilaku yang terjadi dapat dimanfaatkan untuk kepentingan hidup individu yang bersangkutan, baik untuk kepentingan masa sekarang maupun masa mendatang. 4) Perubahan yang bersifat positif; Perubahan perilaku yang terjadi bersifat normatif dan menunjukkan ke arah kemajuan. 5) Perubahan yang bersifat aktif; Untuk memperoleh perilaku yang baru, individu yang bersangkutan aktif berupaya melakukan perubahan. 6) Perubahan yang bersifat permanen; Perubahan perilaku yang diperoleh dari proses belajar cenderung menetap dan menjadi bagian yang melekat dalam dirinya. 7) Perubahan yang bertujuan dan terarah; Individu melakukan kegiatan belajar pasti ada tujuan yang ingin dicapai, baik tujuan jangka pendek, jangka menengah maupun jangka panjang. 8) Perubahan perilaku secara keseluruhan; Perubahan perilaku belajar bukan hanya sekedar memperoleh pengetahuan semata, tetapi termasuk memperoleh pula perubahan dalam sikap dan keterampilannya.
Sekolah yang dijadikan lokasi penelitian tindakan kelas ini adalah SMP Negeri 4 Denpasar. Sekolah terletak di jalan Gunung Agung Denpasar. Lingkungan sekolah tempat dilakukan penelitian ini cukup baik dalam mendukung lancarnya pelaksanaan proses belajar mengajar karena aman, nyaman,tertata rapi, rindang, tidak bising serta masyarakat sekitar mendukung keberadaan sekolah ini. Untuk penelitian ini peneliti memilih rancangan penelitian tindakan yang disampaikan oleh Kemendiknas seperti terlihat pada Gambar 01. Subjek penelitian tindakan kelas ini adalah siswa kelas VII-6 di SMP Negeri 4 Denpasar yang jumlahnya 36 orang. Objek dari penelitian tindakan kelas ini adalah peningkatan kemampuan writing siswa kelas VII-6 semester II tahun pelajaran 2017/2018 SMP Negeri 4 Denpasar. Penelitian ini dilakukan dari bulan Januari 2018 sampai bulan Mei 2018. Untuk merekam data hasil pelaksanaan tindakan setelah berlangsungnya siklus, guru selaku peneliti menggunakan observasi melalui tes prestasi belajar. Metode yang digunakan untuk menganalisis data hasil penelitian ini adalah metode deskriptif baik untuk data kualitatif maupun kuantitatif.

\section{METODE PENELITIAN}




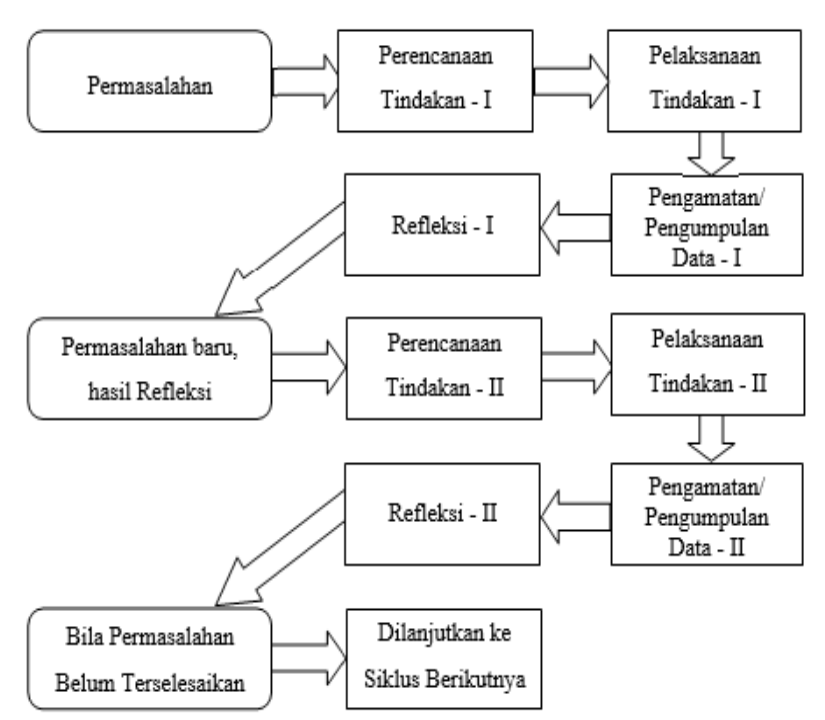

Gambar 01. Rancangan Penelitian

\section{PEMBAHASAN}

Pelaksanaan yang dilakukan pada kegiatan awal diperoleh data siswa yang memperoleh nilai di atas KKM sebanyak 3 orang $(8,33 \%), 10$ orang siswa $(27,78 \%)$ memperoleh nilai sama dengan KKM sedangkan sisanya sebanyak 23 orang siswa $(63,89 \%)$ memperoleh nilai di bawah KKM. Ketidakberhasilan tersebut banyak dipengaruhi oleh faktor ketidak siapan guru dalam membuat perencanaan, profesionalisme guru dalam melaksanakan pembelajaran dan kesiapan guru dalam mempelajari keilmuan-keilmuan yang mesti ditetapkan dalam melaksanakan proses pembelajaran. Kelebihan yang telah diperbuat adalah peneliti sebagai guru di SMP Negeri 4 Denpasar telah berupaya semaksimal mungkin agar peningkatan mutu pendidikan di sekolah ini dapat berjalan sesuai harapan. Oleh karena itu peneliti berupaya membuat desain pembelajaran baru yang dilaksanakan pada siklus I menggunakan model pembelajaran kooperatif Think-Pair-Share untuk meningkatkan kemampuan writing siswa kelas VII-6. Dengan belajar berkelompok dan berkolaborasi saling mengisi kekurangan diharapkan kemampuan writing dapat mengalami meningkat.

Deskripsi terhadap pelaksanaan penelitian di siklus I ini adalah dari 36 orang siswa yang diteliti, 10 orang siswa $(27,78 \%)$ memperoleh nilai diatas KKM, 16 orang siswa $(44,44 \%)$ memperoleh nilai sama dengan KKM sedangkan yang lain sebanyak 10 orang siswa $(27,78 \%)$ masih memperoleh nilai dibawah KKM. Untuk analisis kuantitatif disampaikan sebagai berikut:

1. Rata-rata (mean) $=\frac{\text { Jumlah nilai }}{\text { Jumlah siswa }}=$

$$
\frac{2.591}{36}=71,97
$$

2. Median (titik tengahnya) dicari dengan mengurut data/nilai siswa dari yang terkecil sampai terbesar. Setelah diurut apabila jumlah data ganjil maka mediannya adalah data yang ditengah. Kalau jumlahnya genap maka dua data yang di tengah dijumlahkan dibagi 2 (dua). Untuk median yang diperoleh dari data siklus I dengan menggunakan cara tersebut adalah: 72,00

3. Modus (angka yang paling banyak/paling sering muncul) setelah diasccending/ diurut. Angka tersebut adalah: 72,00

4. Untuk persiapan penyajian dalam bentuk grafik maka hal-hal berikut dihitung terlebih dahulu.

$$
\begin{aligned}
& \text { a) Banyak kelas }(\mathrm{K})=1+3,3 \times \log (\mathrm{N}) \\
& \begin{array}{l}
=1+3,3 \times \log 36 \\
=1+(3,3 \times 1,56) \\
=1+5,15=6,15 \rightarrow 6
\end{array}
\end{aligned}
$$

b) Rentang kelas (r) = skor maks - skor $\min$

$$
\begin{aligned}
& =78-65 \\
& =13
\end{aligned}
$$


c) Panjang kelas interval (i) $=\frac{r}{K}=\frac{13}{6}=$

\section{$2,17 \rightarrow 3$}

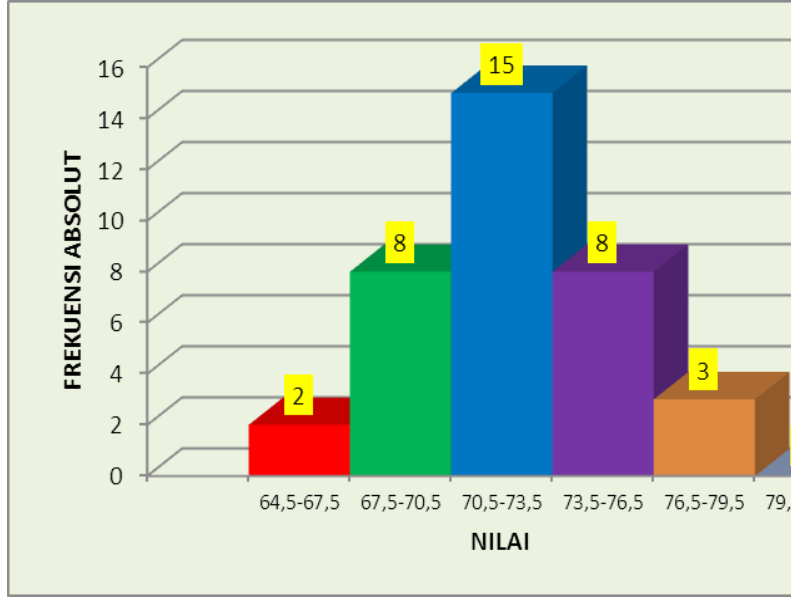

Gambar 02. Histogram pada Siklus I

Hasil pengamatan yang diperoleh pada siklus II adalah: dari 36 orang siswa yang diteliti ternyata 33 orang siswa (91,67\%) memperoleh nilai di atas KKM dan 3 orang siswa $(8,33 \%)$ memperoleh nilai sama dengan KKM. Ini berarti sudah seluruh siswa (100\%) mampu meningkatkan kemampuan writing mereka. Itu artinya bahwa mereka sudah berkembang melebihi indikator yang dituntut. Dari kegiatan pembelajaran setelah diamati, semua siswa sudah menyertakan hasil pekerjaannya. Mereka sudah dipacu dengan apa yang telah dihasilkan oleh teman-temannya. Kesimpulan refleksinya adalah bahwa peningkatan kemampuan writing siswa sudah sangat baik. Untuk analisis kuantitatif disampaikan sebagai berikut:

1. Rata-rata $($ mean $)=$

2. Median (titik tengahnya) dicari dengan mengurut data/nilai siswa dari yang terkecil sampai terbesar. Setelah diurut apabila jumlah data ganjil maka mediannya adalah data yang ditengah. Kalau jumlahnya genap maka dua data yang di tengah dijumlahkan dibagi 2 (dua). Untuk median yang diperoleh dari data siklus I dengan menggunakan cara tersebut adalah: 82

3. Modus (angka yang paling banyak/paling sering muncul) setelah diasccending/ diurut. Angka tersebut adalah: 80

4. Untuk persiapan penyajian dalam bentuk grafik maka hal-hal berikut dihitung terlebih dahulu.

a) Banyak kelas $(\mathrm{K})=1+3,3 \times \log$ (N)

$$
\begin{aligned}
& =1+3,3 \times \log 36 \\
& =1+(3,3 \times 1,56) \\
& =1+5,15=6,15 \rightarrow 6
\end{aligned}
$$

b) Rentang kelas (r) = skor maks skor min

$$
=92-72=20
$$

c) Panjang kelas interval (i) $=\frac{r}{K}=\frac{20}{6}=$ $3,33 \rightarrow 4$

\section{Gambar 03. Histogram Siklus II}




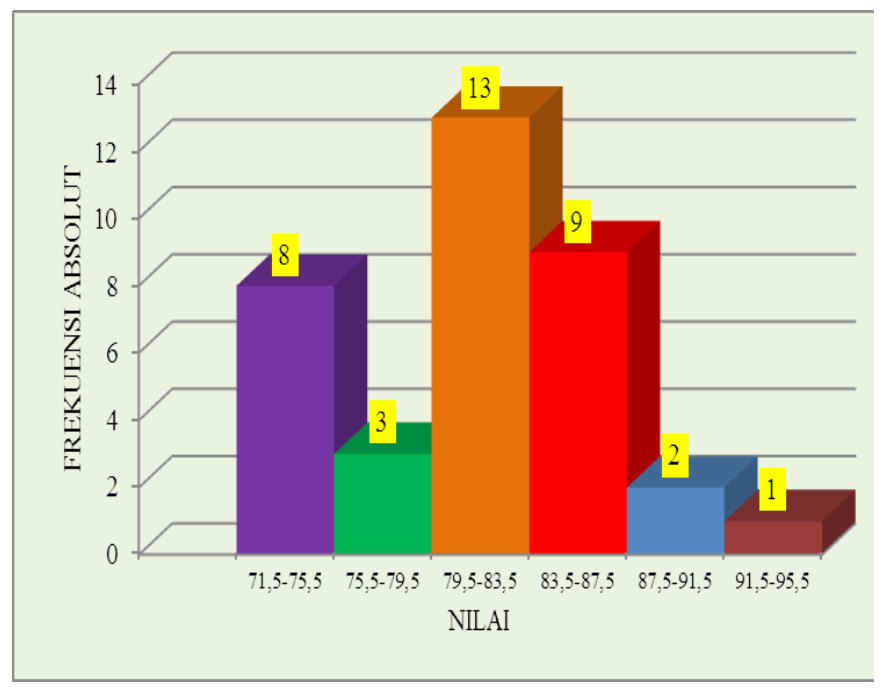

Data awal yang diperoleh dengan rata-rata menunjukkan bahwa kemampuan siswa dalam mata pelajaran Bahasa Inggris khususnya kemampuan writing masih sangat rendah mengingat kriteria ketuntasan minimal (KKM) untuk mata pelajaran Bahasa Inggris di SMP Negeri 4 Denpasar adalah 72,00. Dengan nilai yang sangat rendah pada awalnya sebesar 67,11 dimana hanya 3 orang siswa $(8,33 \%)$ memperoleh nilai di atas KKM, 10 orang siswa $(27,78 \%)$ memperoleh nilai sama dengan KKM sedangkan 23 orang siswa $(63,89 \%)$ yang lainnya belum mencapai KKM sedangkan prosentase ketuntasan belajar mereka baru mencapai 36,11\%.

Dengan penerapan model pembelajaran kooperatif Think-Pair-Share yang benar sesuai teori yang ada, peningkatan rata-rata prestasi belajar siswa pada siklus I dapat diupayakan dan mencapai rata-rata 71,97. Dimana ada 11 orang siswa $(30,56 \%)$ memperoleh nilai di atas KKM, 15 orang siswa $(41,67 \%)$ memperoleh nilai sama dengan KKM sedangkan 10 orang siswa $(27,78 \%)$ yang lainnya belum mencapai KKM. Sedangkan prosentase ketuntasan belajar mereka baru mencapai $72,22 \%$.

Pada siklus ke II perbaikan prestasi belajar siswa diupayakan lebih maksimal dengan peneliti membuat perencanaan yang lebih baik, menggunakan alur dan teori dari model pembelajaran kooperatif dengan benar dan lebih maksimal. Peneliti giat memotivasi siswa agar giat belajar, memberi arahan-arahan, menuntun mereka untuk mampu menguasai materi pelajaran pada mata pelajaran Bahasa Inggris lebih optimal. Akhirnya dengan semua upaya tersebut peneliti mampu meningkatkan prestasi belajar siswa pada siklus II menjadi rata-rata 80,58 dimana ada 33 orang siswa $(91,67 \%)$ memperoleh nilai di atas KKM dan 3 orang siswa (8,33\%) memperoleh nilai sama dengan KKM. Upaya-upaya yang maksimal tersebut menuntun kepada penelitian bahwa model pembelajaran kooperatif Think-Pair-Share mampu meningkatkan kemampuan writing siswa.

\section{SIMPULAN DAN SARAN}

Bertitik tolak dari pemicu rendahnya prestasi belajar ada pada faktorfaktor seperti metode yang digunakan guru, sehingga penggunaan atau penggantian metode diperlukan, akibatnya peneliti mencoba model pembelajaran kooperatif Think-Pair-Share dalam upaya untuk dapat memecahkan permasalahan yang ada.

Dari data awal ada 23 orang siswa mendapat nilai dibawah KKM dan pada siklus I menurun menjadi 10 orang siswa dan siklus II tidak ada siswa yang mendapat nilai di bawah KKM. Dari ratarata awal 67,11 naik menjadi 71,97 pada siklus I dan pada siklus II naik menjadi 80,58 . Ketuntasan belajar dari $36,11 \%$ pada kegiatan awal menjadi 72,22\% semakin meningkat pada siklus II menjadi 100\%. Dari semua data pendukung pembuktian pencapaian tujuan pembelajaran dapat disampaikan bahwa 
model pembelajaran kooperatif think-pairshare dapat memberi jawaban yang diharapkan sesuai tujuan penelitian ini. Semua ini dapat dicapai adalah akibat kesiapan dan kerja keras peneliti dari sejak pembuatan proposal, review hal-hal yang belum bagus bersama teman-teman guru, penyusunan kisi-kisi dan instrumen penelitian, penggunaan sarana trianggulasi data sampai pada pelaksanaan penelitian yang maksimal.

Berdasarkan temuan yang sudah disimpulan dari hasil penelitian, dalam upaya mencapai tujuan pembelajaran dapat disampaikan saran-saran sebagai berikut: 1) Dalam melaksanakan proses pembelajaran pada mata pelajaran Bahasa Inggris, penggunaan model kooperatif diharapkan menjadi pilihan dari beberapa model yang ada mengingat model ini telah terbukti dapat meningkatkan kerjasama, berkreasi, bertindak aktif, bertukar informasi, mengeluarkan pendapat, bertanya, berdiskusi, berargumentasi dan lain-lain. 2) Walaupun penelitian ini sudah dapat membuktikan efek utama dari model kooperatif dalam meningkatkan prestasi belajar, sudah pasti dalam penelitian ini masih ada hal-hal yang belum sempurna dilakukan, oleh karenanya kepada peneliti lain yang berminat meneliti topik yang sama untuk meneliti bagian-bagian yang tidak sempat diteliti. 3) Selanjutnya untuk adanya penguatan-penguatan, diharapkan bagi peneliti lain untuk melakukan penelitian lanjutan guna verifikasi data hasil penelitian.

\section{DAFTAR PUSTAKA}

Astrini. (2005). Pengaruh Penerapan Model Pembelajaran Kooperatif Tipe Numered-Head-Together (NHT) dalam Pembelajaran Matematika Terhadap Prestasi Belajar Siswa
Kelas II SMP Negeri 1 Sidemen. IKIP Negeri Singaraja.

Depdiknas. (2008). Strategi Pembelajaran dan Pemilihannya. Direktorat Tenaga Kependidikan Direktorat Jenderal Peningkatan Mutu Pendidik Dan Tenaga Kependidikan Departemen Pendidikan Nasional.

Jatmiko. (2008). Strategi Belajar Mengajar. PT Rineka Cipta.

Mahaputri. (2003). Writing dan Teknikteknik Pembelajarannya. http://mahaputri.blogspot.com/2011/0 4/writing-dan-teknik-teknik.html

Sanjaya, W. (2006). Strategi Pembelajaran Berorientasi Standar Proses Pendidikan. Kencana Prenada Media Group.

Suryabrata, S. (2002). Pengembangan Alat Ukur Psikologis. Andi.

Uno. (2008). Perencanaan Pembelajaran. Bumi Aksara.

Winkel. (2004). Psikologi Pengajaran. Media Abadi. 